\title{
SUSTAINABLE BEST PRACTICES OF EUROPEAN CULINARY FESTIVALS
}

\author{
Bence Csapody \\ Katalin Ásványi \\ Melinda Jászberényi
}

https://doi.org//10.20867/tosee.06.11

\begin{abstract}
Purpose - The COVID-19 pandemic has a major impact on the operation of hospitality establishments today. Conscious entrepreneurs have exploited this critical situation to carry out self-revision and examined the opportunities to open towards new models. But what is the situation with culinary events? The period of recovery after a crisis often shifts in a new direction of operation such as the emergence of sustainable approaches in gastronomy and tourism. In order to showcase exemplary methods, our main research question is "what sustainable practices are applied in European culinary festivals"?

Methodology - The following study is primarily based on the identification of best practices from European gastronomic festivals. Using benchmarking methodology is a complex, systematic process including the creation of new standards in order to provide ideas for event organizers to make their festivals more sustainable.

Findings - The results were allocated within four dimensions (ingredients and food served; organization; communication and programs; local communities and culture), assigning each practice to specific aspects by dimension. Based on the results, we can state that "local thinking" appears across the dimensions in exemplary practices, regarding the culture of settlements hosting the festivals as well as the procurement of ingredients. Moreover, in connection with the social pillar of sustainability, while promoting local family businesses, the transfer and preservation of local culture by the festivals must also play a key role.

Contribution - We were seeking functional implementation ideas that can help strengthen sustainable gastronomic tourism in the post-crisis recovery period. Our goal is to detect and showcase these examples and raise the awareness of event organizers.
\end{abstract}

Keywords: sustainability, culinary festival, gastronomic event, COVID-19, gastronomy, hospitality.

\section{INTRODUCTION}

By the spread of the coronavirus, economic life has fundamentally changed everywhere in the world, without exception. Whilst food delivery and take-away provided a chance of survival to some of the providers in the hospitality sector, organization of events has been subject to several major restrictions or even banned totally in a large number of European countries. By the appearance of coronavirus vaccines and the commencement of mass vaccinations in many parts of the continent, we took the first steps on the road to recovery. At the time of writing this paper, however, we cannot talk about the crisis in the past tense, its long-term economic effects are unpredictable. Nevertheless, it can therefore be concluded that the economic systems have gone through a significant change recently and the ideological question is which path to choose. According to experts, it is not yet necessary to bury the age of globalization (Karabell 2020; Elliott 2020); recent 
ToSEE - Tourism in Southern and Eastern Europe, Vol. 6, pp. 155-165, 2021.

B. Csapody, K. Ásványi, M. Jászberényi: SUSTAINABLE BEST PRACTICES OF EUROPEAN CULINARY ...

statements expect a significant change in the system of value chains (Kantrup et al. 2020) as it happened during the economic crisis that erupted in 2008 (Van Til 2020).

The main research question of our study is "what sustainable practices are applied in European culinary festivals?". In our study, we attempt to outline the "sustainable" vision ahead of gastronomic events based on recent literature and an empirical best practice analysis we carried out. Firstly, we give a short review of literature on sustainable hospitality, then we present the results of our recent research on sustainable "best practices" in gastronomic events, along the dimensions and criteria defined by this research. The research was carried out online by processing the information available on the events' own website and social networking sites as well as reports and blog posts about festivals. Beyond the academic aims, the purpose of our research is to outline exemplary initiatives to event organizers so that festivals may realize a more sustainable method of operation after restart.

\section{SUSTAINABLE WAYS IN HOSPITALITY}

The COVID-19 pandemic has fundamentally impacted the hospitality industry, evoking a structural change in the field (Neise et al. 2021). According to experts, the period of recovery may lead to an opening to new directions in general management fundamentally affecting the field of hospitality management as well (Breier et al. 2021). Such a new direction could be the promotion of a sustainable approach and, as part of this, the spread of a raw material procurement strategy based on local producers in the field of gastronomy. Sustainability is usually analyzed along three pillars - examining the environmental, economic and social aspects of a given issue. Nevertheless, when looking at the issue of sustainability, we can see that while there have been a number of studies on tourism in general in recent decades, the academic sphere has focused less comprehensively on the issue of restaurant hospitality and the sustainability of food served (Jacobs and Klosse 2016).

One major milestone in the spread of sustainable hospitality concepts was the beginning of the slow movement in 1986 with the protest of an Italian gastro blogger, called Carlo Petrini. He spoke out against the opening of a fast food restaurant at the Spanish Steps, one of the most important symbols of Rome. Three years later, in 1989, the base document of slow food was born in Paris proclaiming the local market's importance, regional traditions and the enjoyment of slowly prepared food (Simonetti and Petrini 2012).

Restaurant menus based on ingredients sourced from as close a source as possible commonly known as zero kilometer food or farm-to-table concept - have become trendy since the early 2000s especially in Western European countries. Firstly, fine dining restaurants had been touched by this phenomenon which later spread into other categories as well. It is important to note that since the millennium, sustainability criteria have gotten less easy to satisfy as systems-based approaches used today take into account a number of other factors.

Kooy (2013) formulated the basis of sustainable food preparation along five "ingredients" in his work analyzing cultural, health, natural, quality and profit aspects of 
ToSEE - Tourism in Southern and Eastern Europe, Vol. 6, pp. 155-165, 2021.

B. Csapody, K. Ásványi, M. Jászberényi: SUSTAINABLE BEST PRACTICES OF EUROPEAN CULINARY ...

this topic. However, Rimmington et al. (2006) identified nine necessary criteria for sustainable food preparation, setting the use of locally produced raw materials and the purchase of products from producers in the region as necessary conditions. However, a research with more than 1,200 consumers showed that the motivation behind buying local products is more about the support for local actors than the product quality itself (Memery et al. 2015).

Experience has shown us that consumers associate sustainable nutrition with a wastefree and at the same time healthy diet, primarily by using domestic ingredients while protecting the environment. Based on a non-representative online survey conducted by the Hungarian Tourism Agency in 2020 with the involvement of the Hungarian population, it can be seen that $20 \%$ of the respondents are committed to sustainable nutrition in this way, while another nearly $30 \%$ consider themself environmentally aware but not yet paying attention to their nutrition from this aspect (Hungarian Tourism Agency 2020).

Emphasizing the role of local ingredients, the European Commission's Communication of 20 May 2020 (COM/2020/381) is about the farm to fork strategy, addressing the values that Europeans attach to food sustainability. In the text, the Commission points to the impact of short value chains on consumers' health and quality of life and states that "consumers should be empowered to choose sustainable food and all actors in the food chain should see this as their responsibility and opportunity" (European Commission 2020). However, the first necessary step to put these theories into practice is to get the role of local product-based thinking recognized by those working in and for the hospitality sector.

\section{METODOLOGY}

Although the topic of sustainable culinary systems is a less researched field by the academic sphere, at the same time it is gaining more and more popularity. The aim of our research is a comprehensive examination of a less studied topic on the one hand, and on the other hand it is essential from a practical point of view as well. Thus we aim to outline possible pathways for market operators that serve them as a "handhold" during the recovery period after COVID- 19 .

The analysis of gastronomic festivals was carried out by a qualitative analysis, in order to get specific information concerning best practices. As Bhutta and Huq $(1999,254)$ defined, "the essence of benchmarking is the process of identifying the highest standards of excellence for products, services, or processes, and then making the improvements necessary to reach those standards - commonly called best practices". According to literature, several different benchmarking models have been developed by academics through the years. Deros et al. (2006) have examined some of the benchmarking frameworks and have classified them into different models. Our research can be considered as a sub-type of "consultant/expert-based models" as these are based on personal opinion and judgment through experience in order to provide consultancy to firms (in this case event organizers) thus making it a more practical oriented method. 
ToSEE - Tourism in Southern and Eastern Europe, Vol. 6, pp. 155-165, 2021.

B. Csapody, K. Ásványi, M. Jászberényi: SUSTAINABLE BEST PRACTICES OF EUROPEAN CULINARY ...

In 1989, Camp has identified the main steps of carrying out a benchmarking analysis which are the following:

1. Identify benchmarking subject

2. Identify benchmarking partners

3. Determine data collection method and collect data

4. Determine current competitive gap

5. Project future performance

6. Communicate findings and gain acceptance

7. Establish functional goals

8. Develop action plans

9. Implement plans and monitor progress

10. Recalibrate the benchmark (Camp 1989).

Our research was carried out with the subject of identifying best practices in sustainable gastronomic festival organizations. Thus we collected culinary festivals of higher quality presenting mainly local products throughout the European Union. The collection was carried out based on our own experiences as well as using different sites and blogs listing such programs.

Table 1: Best practices named in this paper (own source)

\begin{tabular}{ll}
\hline Festival & Location \\
\hline Blenheim Palace Food Festival & Woodstock, UK \\
The Milan Coffee Festival & Milan, Italy \\
Gourmet Festival Düsseldorf & Düsseldorf, Germany \\
International Oyster and Seafood Festival & Galway, Ireland \\
Taste of Amsterdam & Amsterdam, Netherlands \\
Oktoberfest & Munich, Germany \\
Taste Florence Food Festival & Florence, Italy \\
Bristol Food Connections & Bristol, UK \\
Beer Passion Weekend & Antwerp, Belgium \\
Edinburgh Food Festival & Edinburgh, UK \\
Seafood Festival of Marisco & O Grove, Spain \\
London Craft Beer Festival & London, UK \\
Bordeaux Wine Festival & Bordeaux, France \\
Copenhagen Cooking and Food Festival & Copenhagen, Denmark \\
\hline
\end{tabular}

Finally, a total of $\mathbf{1 4}$ events (see Table 1) have been analyzed based on the following dimensions:

- Ingredients and food served

- Organization

- Communication and programs

- Local culture and communities.

Due to the coronavirus pandemic, we faced some challenges in data collection as some of these events could not have been organized in 2020 due to Covid-19 restrictions. However, data collection could be carried out online, using the events' websites, 
ToSEE - Tourism in Southern and Eastern Europe, Vol. 6, pp. 155-165, 2021.

B. Csapody, K. Ásványi, M. Jászberényi: SUSTAINABLE BEST PRACTICES OF EUROPEAN CULINARY ...

Facebook, Instagram and other social media pages as well as collecting data from different reviews and reports available online of these events.

\section{FINDINGS}

The benchmarking analysis of gastronomic events revealed that while some environmentally sustainable practices are widely used in festivals, economical and social aspects are less considered when organizing such events. In the development of the dimensions of this analysis we attempted to equally focus on all 3 pillars of sustainability.

\subsection{Ingredients and food served}

Our research shows that in most cases, the sustainability criterion appears in terms of ingredients as well as the food and beverages offered. In the case of the Bordeaux Wine Festival, there is a particular emphasis on local products, with wines and products used solely from the Bordeaux Wine Region. The theme of the Taste of Amsterdam event also touches on several pillars of sustainability, as domestic restaurants and producers take part, offering typical domestic flavors.

The theme of the Taste Florence Food Festival is also based on regional culinary traditions and ingredients, counting on the participation of local producers and restaurants producing quality ingredients while the "slow food movement" also plays an essential role in its concept.

In addition to local ingredients, an excellent example of seasonal thinking is the International Oyster and Seafood Festival in Galway (Ireland), which is built specifically on the oyster season. It is held in September, which is considered the beginning of the oyster season. A similar organizational concept can be found at the Edinburgh Food Festival, where local sustainable fish production, honey production and local crops are in focus.

Moreover, we can observe highly sustainable practices at the Copenhagen Cooking and Food Festival. In addition to the practices presented above, such as sustainable ingredients, locally grown vegetables, and foods containing herbs, there are also programs that focus on self-produced ingredients that we will discuss later under the dimension of "communications and programs".

Nowadays, it is also crucial to expect visitors with different intolerances. A good practice of this can be seen in the case of The Milan Coffee Festival, bearing Alpro as a main sponsor, also allowing the consumption of plant-based milks. Neither can events with a long tradition avoid the new, plant-based trends in culinary. Munich's Oktoberfest offers vegan beers along with vegan and vegetarian versions of traditional Bavarian food more and more frequently.

However, the use of local products alone does not meet the criteria of sustainability, as in many cases local production is due to overexploitation. Bristol Food Connections may be a good example in this respect, with a focus on processing non-endangered fish in parallel with the preference for fairly traded and organic local products. 
ToSEE - Tourism in Southern and Eastern Europe, Vol. 6, pp. 155-165, 2021.

B. Csapody, K. Ásványi, M. Jászberényi: SUSTAINABLE BEST PRACTICES OF EUROPEAN CULINARY ...

\subsection{Organization}

Regarding sustainable organization and event management, the focus is usually on minimizing the amount of waste generated. This is one of the reasons for the increasing use of paperless ticketing (e.g., The Milan Coffee Festival) and the spread of re-glasses at events (e.g., Beer Passion Weekend and London Craft Beer Festival), however, these are no longer novelties today. The Edinburgh Food Festival, as a partner of the Assembly Festival, also strives to minimize and recycle waste, thus all venues are equipped with paper, cardboard, glass, mixed recycling, food and general waste bins while all plastics used in the event are fully recyclable. As part of the \#TheLastStraw campaign, organizers banned the use of one-way straws as well. We can see that waste management in general, and the reduction of food waste in particular, is an issue for festival organizers, so does Blenheim Palace Food Festival by supporting Too Good To Go application fighting against food waste. However, in many cases (e.g., Bristol Food Connections) no concrete proposals for action are made. In contrast, Oktoberfest has developed its own waste management system. Organizers banned disposable plates, utensils and cutleries, and garbage is collected strictly selectively.

In addition to the field of waste management, Munich's beer festival is also an example for green energy resources. The organizers of the festival claim that the annual emissions of 1,000 tons of carbon dioxide will be prevented by using environmentally friendly, renewable energy sources (so-called "M-Ökostrom" and "M-Ökogas") at the event. In addition, entertainment items (such as roller coasters and carousels) work with biodegradable hydraulic oil only. Solar panels are used in many places, while tents and other attractions are lit with LED bulbs. We can also find an exemplary initiative for the recycling of wastewater at the beer festival: in many tents the sink water is reused in the restrooms.

The example of the Gourmet Festival Düsseldorf shows that not only can festival organizers exercise their discretion for environmentally sustainable operation, but they can also stipulate in the exhibitor contract that exhibitors are obliged to behave in an environmentally conscious manner. From an organizational point of view, it is also important not only to formulate expectations and prohibitions (such as banning PET bottles from a given event), but also to support visitors in sustainability steps, as shown by the free drinking water provided by Bristol Food Connection and Taste of Amsterdam among others. On top of that, Copenhagen Cooking and Food Festival may serve as an outstanding example of in-depth sustainable planning, where all fabrics from chef coats to tablecloths are made from recycled and reusable materials.

Not only green practices on the site make an event sustainable, but also considering a number of other related issues is essential. Here we can list for example the way of approaching the festival, the issue of transport, which has a significant impact on the environment as well. As Taste of Amsterdam, so is Blenheim Palace Food Festival promoting green transport. The Blenheim Palace Food Festival aims to create a greener future, achieving a carbon-neutral state by 2025. As part of this, a goal has been set for 50 percent of visitors to arrive in a carbon-friendly way, which will also be supported by the construction of a cycling and walking route. Thanks to their collaboration with Good Journey, they have been able to make transport sustainable. Visitors are encouraged to arrive in a green way (by train, bus, bicycle or on foot) for a 30 percent discount on the ticket price. 
ToSEE - Tourism in Southern and Eastern Europe, Vol. 6, pp. 155-165, 2021.

B. Csapody, K. Ásványi, M. Jászberényi: SUSTAINABLE BEST PRACTICES OF EUROPEAN CULINARY ...

\subsection{Communication and programs}

In addition to the steps discussed before, analyzing communication habits of event organizers is crucial. Thus, to help visitors understand sustainable practices, a "Sustainability" menu item is available on Taste of Amsterdam's website. Here, "green" steps of organizers are listed along with information on how guests can enjoy their visit in an environmentally friendly way. In addition, several environmentally friendly ways are promoted how people can reach the event's site.

Similarly, environmental awareness also plays a key role in the communication of Oktoberfest, attracting visitors with environmentally conscious steps communicated on their website. Bristol Food Connections' social media pages regularly address sustainability issues, including Instagram images and captions mentioning the importance of consuming from local producers. One of the highlights of the festival is the BBC Food and Farming Awards, which has been established to celebrate those who work hard every day to make people eat healthier. Launched in 2000, the initiative has been expanded over the years with 2 new categories, the Best Drinks Producer 2010 and the Future Food Awards in 2016.

Also, Bordeaux Wine Festival draws special attention of visitors to their responsibility to protect the environment. Supporting local producers, respect and responsibility for the environment, and the cooperation with partners committed to sustainable operation are essential for the festival. On the Copenhagen Cooking and Food Festival's Facebook and Instagram pages, however, recommendations of local restaurants, cafes and organic farms are regularly posted throughout the year.

In order to reach a lasting sustainable impact on gastronomic festivals, practices may be showcased that can be applied in our lives as well. Educational programs for visitors are considered particularly important in event organization. The Edinburgh Food Festival aims to reinforce visitors' sense of sustainability through film projections. At the most recent festival, Zev Robinson's documentaries on local food extraction and sustainable fishing in the Scottish Highlands were screened to visitors. Also noteworthy is the Copenhagen Cooking and Food Festival, which not only hosts the "most sustainable dinner in the world", but also educates visitors on how to produce vegetables for themselves through various programs organized during the festival.

Additionally, during Milan Coffee Festival, Lavazza Talk was organized in 2018 for visitors to participate in workshops on sustainable coffee cultivation and the ICO on sustainability. Similarly, at Bristol Food Connections, different programs were organized on slow food, vegan lifestyle and plant-based diet.

\subsection{Local culture and communities}

Examining events with regards to their role in supporting local communities and sustaining their cultures, Edinburgh Food Festival can be considered as a flagship of sustainability regarding local social and thus, local economical aspects. The festival provides an opportunity for mostly local, family businesses to present themselves to 
ToSEE - Tourism in Southern and Eastern Europe, Vol. 6, pp. 155-165, 2021.

B. Csapody, K. Ásványi, M. Jászberényi: SUSTAINABLE BEST PRACTICES OF EUROPEANCULINARY ...

visitors. As only local market players participate, revenues will return to local producers, distributors and providers. Another good example of support for local actors and employees is the International Oyster and Seafood Festival, where many restaurants take part in the event every year. Moreover, to stimulate local tourism, organizers promote local providers (such as available accommodation) on the event's website.

The Seafood Festival of Marisco, which could not have taken place without the work of local fishermen, also fits into this line. An important message of the event is to introduce visitors to sustainable fishing, to promote local gastronomic culture and to connect the local population with visitors from further afield. Similarly, Taste Florence Food Festival has been established with the aim of celebrating and sharing widely Florentine's culture.

Table 2: Criteria for sustainable gastronomic events (own source)

\begin{tabular}{|c|c|c|}
\hline Dimensions & Criteria & Examples \\
\hline \multirow{5}{*}{$\begin{array}{l}\text { Ingredients } \\
\text { and food } \\
\text { served }\end{array}$} & $\begin{array}{l}\text { use of local ingredients } \\
\text { and products }\end{array}$ & $\begin{array}{l}\text { concept based on local ingredients and wines (Bordeaux } \\
\text { Wine Festival) }\end{array}$ \\
\hline & $\begin{array}{l}\text { protection of endangered } \\
\text { species, fight against } \\
\text { overexploitation }\end{array}$ & $\begin{array}{l}\text { practices for endangered species and against overfishing in } \\
\text { gastronomy (Bristol Food Connections) }\end{array}$ \\
\hline & $\begin{array}{l}\text { use of seasonal } \\
\text { ingredients }\end{array}$ & $\begin{array}{l}\text { event organized during the oyster season (International } \\
\text { Oyster and Seafood Festival) }\end{array}$ \\
\hline & organic products & $\begin{array}{l}\text { promotion of local organic products (Bristol Food } \\
\text { Connections) }\end{array}$ \\
\hline & $\begin{array}{l}\text { food offers for visitors } \\
\text { with food intolerances } \\
\text { and/or special dietary } \\
\text { requirements }\end{array}$ & $\begin{array}{l}\text { vegan beers and vegan version of traditional Bavarian dishes } \\
\text { (Oktoberfest); use of alternative milk (The Milan Coffee } \\
\text { Festival) }\end{array}$ \\
\hline \multirow{8}{*}{ Organization } & waste reduction & $\begin{array}{l}\text { paperless, electronic ticketing (The Milan Coffee Festival); } \\
\text { ban on disposable plates, cutleries, cups and straws (Beer } \\
\text { Passion Weekend, Oktoberfest, Edinburgh Food Festival); } \\
\text { providing drinking water to reduce the use of bottled drinks } \\
\text { (Taste of Amsterdam, Bristol Food Connection) }\end{array}$ \\
\hline & $\begin{array}{l}\text { activities against food } \\
\text { waste }\end{array}$ & $\begin{array}{l}\text { promoting Too Good To Go application against food waste } \\
\text { (Blenheim Palace Food Festival) }\end{array}$ \\
\hline & $\begin{array}{l}\text { selective waste } \\
\text { collection and recycling }\end{array}$ & $\begin{array}{l}\text { setting strict waste selection rules (Edinburgh Food Festival, } \\
\text { Oktoberfest) }\end{array}$ \\
\hline & $\begin{array}{l}\text { sustainable energy } \\
\text { management }\end{array}$ & $\begin{array}{l}\begin{array}{l}\text { environmentally friendly, renewable energy sources } \\
\text { (Oktoberfest) }\end{array} \\
\end{array}$ \\
\hline & $\begin{array}{l}\text { environmentally } \\
\text { conscious water } \\
\text { management }\end{array}$ & reuse of gray water (Oktoberfest) \\
\hline & $\begin{array}{l}\text { use of environmentally } \\
\text { friendly and sustainable } \\
\text { tools }\end{array}$ & $\begin{array}{l}\text { all fabrics made of recycled and reusable materials } \\
\text { (Copenhagen Cooking and Food Festival) } \\
\text { LED bulbs and degradable hydraulic oil (Oktoberfest) }\end{array}$ \\
\hline & $\begin{array}{l}\text { expecting } \\
\text { environmentally } \\
\text { conscious behavior } \\
\text { from exhibitors }\end{array}$ & $\begin{array}{l}\text { requiring environmentally conscious behavior in the } \\
\text { exhibitor contract } \\
\text { (Gourmet Festival Düsseldorf) }\end{array}$ \\
\hline & sustainable transport & $\begin{array}{l}\text { encouraging the use of environmentally friendly means of } \\
\text { transport (Taste of Amsterdam); discounted ticket if using } \\
\text { "green" means of transport (Blenheim Palace Food Festival) }\end{array}$ \\
\hline
\end{tabular}


ToSEE - Tourism in Southern and Eastern Europe, Vol. 6, pp. 155-165, 2021.

B. Csapody, K. Ásványi, M. Jászberényi: SUSTAINABLE BEST PRACTICES OF EUROPEAN CULINARY ...

Table 2 (continued)

\begin{tabular}{|c|c|c|}
\hline Dimensions & Criteria & Examples \\
\hline \multirow{5}{*}{$\begin{array}{l}\text { Communication } \\
\text { and programs }\end{array}$} & $\begin{array}{l}\text { targeted communication } \\
\text { of sustainable practices }\end{array}$ & $\begin{array}{l}\text { "Sustainability" menu item on the website (Taste of } \\
\text { Amsterdam) }\end{array}$ \\
\hline & $\begin{array}{l}\text { rewarding sustainable } \\
\text { examples }\end{array}$ & $\begin{array}{lcccc}\text { BBC Food and Farming Awards (Bristol Food } \\
\text { Connections) }\end{array}$ \\
\hline & $\begin{array}{l}\text { promotion of local market } \\
\text { operators, cooperation } \\
\text { with them }\end{array}$ & $\begin{array}{l}\text { promoting sustainable behavior on community platforms } \\
\text { (Bristol Food Connections); promotion of local service } \\
\text { providers on their own online interfaces (Copenhagen } \\
\text { Cooking and Food) }\end{array}$ \\
\hline & $\begin{array}{l}\text { educating visitors on } \\
\text { sustainability issues }\end{array}$ & $\begin{array}{l}\text { screening of documentaries at the festival (Edinburgh } \\
\text { Food Festival); workshop on sustainable coffee production } \\
\text { (The Milano Coffee Festival) }\end{array}$ \\
\hline & $\begin{array}{l}\text { presentation of } \\
\text { sustainable practices }\end{array}$ & $\begin{array}{l}\text { organizing an exemplary, sustainable dinner (Edinburgh } \\
\text { Food Festival); organizing workshops on home vegetable } \\
\text { growing (Copenhagen Cooking and Food Festival) }\end{array}$ \\
\hline \multirow{3}{*}{$\begin{array}{l}\text { Local } \\
\text { communities } \\
\text { and culture }\end{array}$} & $\begin{array}{l}\text { cooperation with local } \\
\text { businesses }\end{array}$ & $\begin{array}{l}\text { providing publicity for domestic family businesses as } \\
\text { exhibitors (Edinburgh Food Festival, International Oyster } \\
\text { and Seafood Festival) }\end{array}$ \\
\hline & $\begin{array}{l}\text { promoting local culinary } \\
\text { traditions }\end{array}$ & $\begin{array}{l}\text { transmission of fish-based local gastronomic culture } \\
\text { (Seafood Festival of Marisco); conservation of Florence's } \\
\text { gastronomic culture (Taste Florence Food Festival) }\end{array}$ \\
\hline & $\begin{array}{l}\text { networking between local } \\
\text { market players and } \\
\text { visitors }\end{array}$ & $\begin{array}{l}\text { strengthening communication between local fishermen } \\
\text { and local population (Seafood Festival of Marisco) }\end{array}$ \\
\hline
\end{tabular}

\section{CONCLUSION}

The research question of our study was "what sustainable practices are applied in European culinary festivals?". Having reviewed some recent relevant literature, many popular gastronomic trends have been highlighted. These include among others the "slow food" movement launched by Carlo Petrini, or the concepts of zero-kilometer food and farm-to-table too. Our analysis has also shown that these concepts have an impact on festivals paying attention to sustainability while local products are gaining more ground in culinary festivals' theme. Almost without any exceptions, the literature considers it essential for sustainable hospitality models to build on local ingredients (e.g., Rimmington et al. 2006 and Kooy 2013). However, it must be acknowledged that in our globalized world, the complete displacement of imported goods would be an unrealistic goal for the hospitality sector, but the application of the 80-20 rule shall be considered a sustainable goal (Kooy 2013). It also seems that for consumers, sustainable nutrition means a waste-free and at the same time healthy diet, primarily by using domestic ingredients and protecting the environment as well.

The criteria set up as a result of our benchmarking research is also in line with all this. The results were allocated within four dimensions (ingredients and food served; organization; communication and programs; local communities and culture), assigning each practice to specific aspects by dimension (see Table 2). Based on the results, we can state that "local thinking" appears across the dimensions in exemplary practices, regarding the culture of settlements hosting the festivals as well as the procurement of 
ToSEE - Tourism in Southern and Eastern Europe, Vol. 6, pp. 155-165, 2021.

B. Csapody, K. Ásványi, M. Jászberényi: SUSTAINABLE BEST PRACTICES OF EUROPEAN CULINARY ...

ingredients. While the spread of organic, seasonal and new dietary thinking has also to be considered when organizing culinary events.

In terms of organization, the analysis revealed that most of the benchmarks are related to water, waste and energy management, although in some cases we have been able to highlight practices that go beyond mainstream examples such as the use of sustainable textiles. The requirement of environmentally conscious behavior in the exhibitor contract can also be an exemplary initiative as well as the promotion of environmentally friendly means of transport. In addition to event management practice, communication activities and organized programs can also play a key role. In addition to communicating sustainable practices, rewarding exemplary initiatives is also important. Benchmarks show that programs can educate visitors, thus incorporating these practices into their daily lives. Nevertheless, in connection with the social pillar of sustainability, in parallel with the promotion of local family businesses, the transfer and preservation of local culture (in this case, local gastronomic culture) by the festivals must also play a key role.

A limitation of the research was that due to the pandemic, events in 2020 were completely restricted in most countries, so we could mainly analyze the previous events in 2018 and 2019. For this reason, we intend to conduct a comprehensive study in the future regarding the practice of gastronomic festivals as well as a comparative analysis with the practices described in the present study.

\section{REFERENCES}

Bhutta, K.S. and Huq, F. (1999), "Benchmarking - Best Practices: An Integrated Approach", Benchmarking. An International Journal, Vol. 6, No. 3, pp. 254-268. https://doi.org/10.1108/1463577991028926

Breier, M., Kallmuenzer, A., Clauss, T., Gast, J., Kraus, S., Tiberius, V. (2021), "The role of business model innovation in the hospitality industry during the COVID-19 crisis", International Journal of Hospitality Management, Vol. 92, https://doi.org/10.1016/j.ijhm.2020.102723

Camp, R.C. (1989), Benchmarking: The Search for Industry Best Practices that Lead to Superior Performance, ASQC Quality Press, Milwaukee, WI.

European Commission (2020), "Communication from the Commission to the European Parliament, The Council, The European Economic and Social Committee and the Committee of the Regions - A Farm to Fork Strategy for a fair, healthy and environmentally-friendly food system" COM/2020/381, Brussels, 20.5.2020.

Deros, B.M., Yusof, S.M. and Salleh, A.M. (2006), "A benchmarking implementation framework for automotive manufacturing SMEs", Benchmarking: An International Journal, Vol. 13, No. 4, pp. 396-430. https://doi.org/10.1108/14635770610676272

Elliott, L. (2020): “Will coronavirus shock the global economy into long-term thinking?", The Guardian, viewed 15 April 2021, https://www.theguardian.com/commentisfree/2020/apr/15/will-coronavirusshock-the-global-economy-into-long-term-thinking-

Hungarian Tourism Agency (2020), “CSR (Corporate Social Responsibility) activities in the Hungarian hospitality sector" (Non-public report), Budapest, Hungary.

Jacobs, G. and Klosse, P. (2016), "Sustainable restaurants: A research agenda", Research in Hospitality Management 2016, Vol. 6, No. 1, pp- 33-36. https://doi.org/10.2989/RHM.2016.6.1.4.1292

Kantrup, A. Sprich, C., Kessels, N. and Mildner, S. (2020), "COVID-19 and Trade: Not the End of Globalization but Changes in Value Chains to be Expected", The American Institute for Contemporary German Studies, Washington, viewed 15 April 2021 https://www.aicgs.org/2020/05/covid-19-and-trade-not-the-end-of-globalization-but-changes-invalue-chains-to-be-expected/

Karabell,Z. (2020), "Will the Coronavirus Bring the End of Globalization? Don't Count on It", The Wall Stree Journal, viewed 15 April 2021, https://www.wsj.com/articles/will-the-coronavirus-bring-the-endof-globalization-dont-count-on-it-11584716305 
ToSEE - Tourism in Southern and Eastern Europe, Vol. 6, pp. 155-165, 2021.

B. Csapody, K. Ásványi, M. Jászberényi: SUSTAINABLE BEST PRACTICES OF EUROPEAN CULINARY ...

Kooy, A. (2013), 5 ingredienten voor beter, verser, gezonder en eerlijker eten, Tuther, Netherlands.

Memery, J., Angell, R., Megicks, P. and Lindgreen, A. (2015), "Unpicking motives to purchase locallyproduced food: analysis of direct and moderation effects", European Journal of Marketing, Vol. 49, No. 7/8, pp. 1207-1233. https://doi.org/10.1108/EJM-02-2014-0075

Neise, T., Verfürth, P., Franz, M. (2021), "Rapid responding to the COVID-19 crisis: Assessing the resilience in the German restaurant and bar industry", International Journal of Hospitality Management, Vol. 96, 102960. https://doi.org/10.1016/j.ijhm.2021.102960

Rimmington, M., Carlton Smith, J., Hawkins, R. (2006), "Corporate social responsibility and sustainable food procurement”, British Food Journal, Vol. 108, No. 10, pp. 824-837. https://doi.org/10.1108/00070700610702082

Simonetti, L. and Petrini, C. (2012) “The ideology of Slow Food”, Journal of European Studies, Vol. 42, No.2, pp. 168-189. https://doi.org/10.1177/0047244112436908

Van Til, F. (2020), "Three scenarios for globalisation in a post-covid-19 world", The Clingendael Spectator, viewed 15 April 2021, https://spectator.clingendael.org/en/publication/three-scenariosglobalisation-post-covid-19-world

Bence Csapody, PhD Student

Corvinus University of Budapest, Institute of Marketing

Fövám square 8. 1093, Budapest, Hungary

bence.csapody@uni-corvinus.hu

Katalin Ásványi, $\mathrm{PhD}$, Associate Professor

Corvinus University of Budapest, Institute of Marketing

Fővám square 8. 1093, Budapest, Hungary

$+36-70-9407866$

katalin.asvanyi@uni-corvinus.hu

Melinda Jászberényi, PhD, Associate Professor habil.

Corvinus University of Budapest, Institute of Marketing

Fővám square 8. 1093, Budapest, Hungary

+36-30-9822854

jaszberenyi@uni-corvinus.hu 